\title{
Sistem Pendukung keputusan pemilihan tenaga kesehatan teladan menggunakan metode Multi-Attribute Utility Theory
}

\author{
Ramadiani Ramadiani a, Auliana rahmah ${ }^{b}$ \\ a,b Ilmu Komputer, Universitas Mulawarman, Samarinda, Indonesia \\ email:aIlkom.ramadiani@gmail.com,baulianrh@gmail.com
}

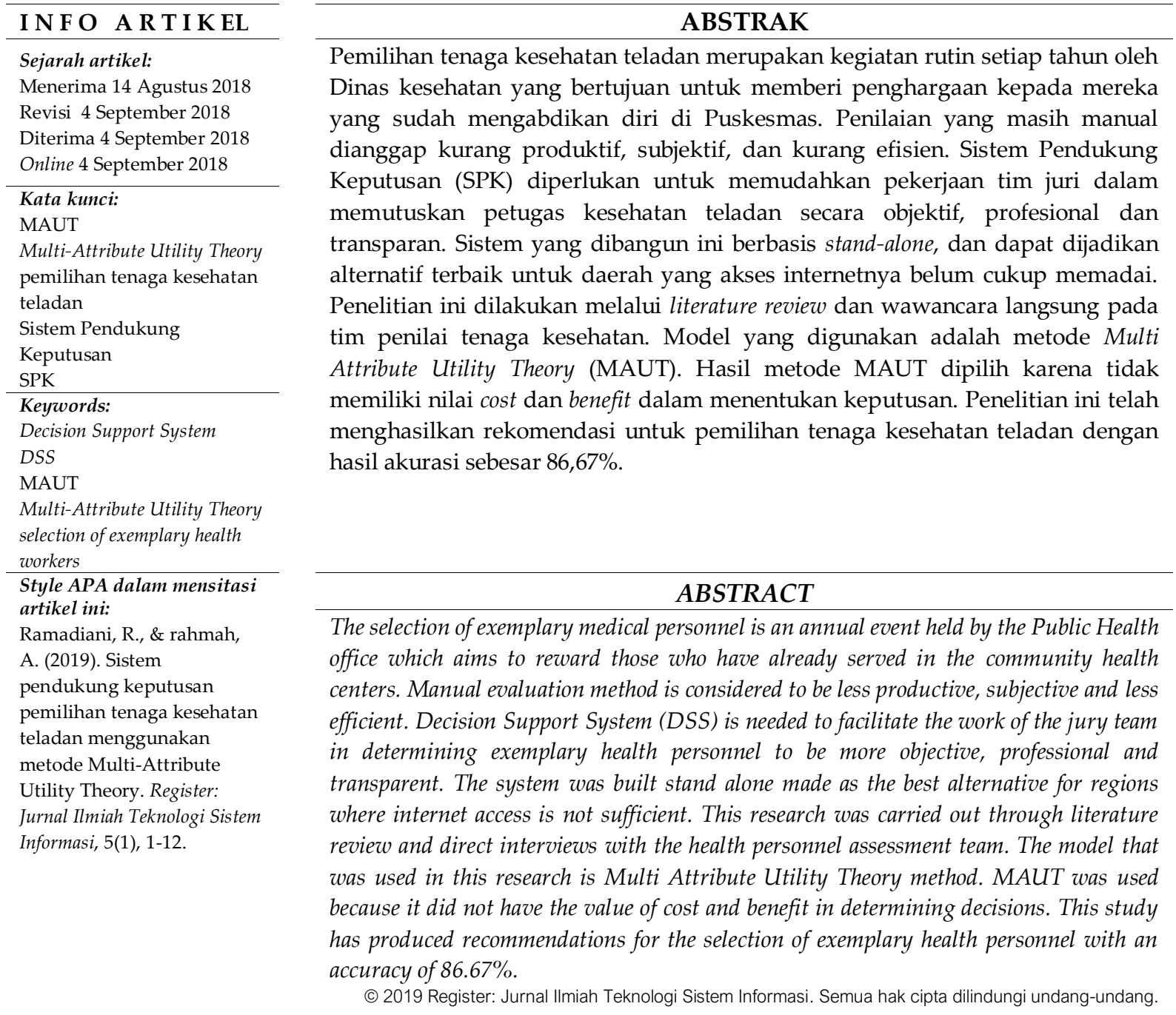

\section{Pendahuluan}

Tenaga Kesehatan adalah mereka yang bekerja untuk mengabdikan diri dalam bidang kesehatan, menguasai pengetahuan dan kompetensi ketrampilan melalui pendidikan formal dibidang kesehatan dengan bukti sertifikat keahlian yang disahkan olah dinas kesehatan (RI, 2014). Pada beberapa keahlian tertentu diperlukan bukti keterampilan dari pendidikan formal untuk melakukan upaya kesehatan. Sebagai motivasi untuk peningkatan kinerja petugas kesehatan yang bekerja di Puskesmas, maka diadakan pemilihan petugas kesehatan teladan. Hal ini diharapkan dapat menjadi salah satu cara untuk menarik minat petugas kesehatan yang bekerja di Puskesmas. Pemilihan tersebut juga dapat 
memotivasi mereka untuk menjadi Petugas kesehatan yang bersikap nasionalis, etis dan professional, menjadi petugas kesehatan yang memiliki semangat pengabdian yang tinggi, berdisiplin, kreatif, berilmu, terampil, berbudi luhur serta menjaga kode etik dan etika profesi petugas kesehatan (RI, 2014).

Cara pemilihan petugas kesehatan yang terbaik atau teladan, masih menggunakan cara manual, terutama dalam menentukan nilai akhir dari seluruh tahapan penilaian. Hal ini tentu kurang produktif dan menambah waktu kerja bagi tim penilai. Selain itu, tim penilai masih dianggap tidak transparan dalam memutuskan siapa petugas kesehatan yang mendapat prestasi nilai tertinggi atau terbaik. Pengembangan sistem komputasi menjadi sangat diperlukan untuk memudahkan pekerjaan tim juri dalam memilih dan menetapkan petugas kesehatan terbaik secara objektif, profesional dan transparan.

Manfaat lain penelitian Sistem Pendukung Keputusan (SPK) yang dibangun dalam penelitian ini adalah cara menetapkan kriteria dan skala penilaian dilakukan melalui literature review, dan wawancara langsung pada tim penilai sebelum mereka memberikan keputusan memilih tenaga kesehatan terbaik. Keputusan yang diambil dapat dipertanggungjawabkan dan persoalan efisiensi waktu juga dapat diatasi melalui penelitian yang mengembangkan SPK. Dengan pertimbangan tersebut, SPK menjadi salah satu solusi sistem yang dapat membantu manusia mengambil keputusan dengan cepat, tepat, objektif, transparan dan konsisten (Ramadiani, Marissa, Jundillah, Azainil, \& Hatta, 2018) (Ramadiani \& Kurniawan, 2018) (Heliana, 2017)

Model yang digunakan dalam sistem pendukung keputusan pemilihan tenaga kesehatan teladan pada penelitian ini adalah menggunakan metode Multi-Attribute Utility Theory (MAUT), metode yang dipilih adalah metode MAUT, karena pada penelitian (Siswo, 2017) tentang penerimaan karyawan PT. PLN Jember memiliki tingkat akurasi 91,57\% dari hasil pengujian menggunakan metode MAUT. Tetapi dalam penelitian Siswo (2017), aplikasi tersebut digunakan secara online, sehingga tidak mendukung pengguna yang tinggal di daerah yang tidak memiliki sinyal atau akses internet yang memadai. Sedangkan penelitian SPK lain yang pernah dilakukan menggunakan metode Simple Multi Attribute Rating Technique (SMART), Simple Additive Weighting (SAW) dan Technique for Order of Preference by Similarity to Ideal Solution (TOPSIS) (Cholil, Pinem, \& Vydia, 2018) (Ramadiani, Marissa, Jundillah, Azainil, \& Hatta, 2018) (Ramadiani \& Kurniawan, 2018). Metode SMART, TOPSIS dan SAW bisa dipertimbangkan untuk digunakan jika ada nilai cost dan benefit dalam pengambilan keputusan tersebut. Berdasarkan hasil dari beberapa penelitian tersebut, metode MAUT dipilih untuk digunakan dalam penelitian SPK ini karena tidak memiliki nilai cost dan benefit dalam menentukan keputusan. SPK yang dibangun ini untuk membantu pemilihan tenaga kesehatan teladan di Dinas Kesehatan Kabupaten Kutai Kartanegara Kalimantan Timur dengan menggunakan metode MAUT berbasis standalone, merupakan alternatif terbaik untuk daerah yang akses internetnya belum cukup memadai.

\section{Studi Pustaka}

\subsection{Pengertian tenaga kesehatan}

Tenaga kesehatan adalah setiap orang yang mengabdikan diri dalam bidang kesehatan, memiliki pengetahuan dan keterampilan melalui pendidikan di bidang kesehatan yang memerlukan kewenangan dalam menjalankan pelayanan kesehatan (RI, 2016). Tenaga kesehatan terdiri dari (Indonesia, 1996):

a. Tenaga medis yaitu dokter atau dokter gigi.

b. Tenaga keperawatan yaitu perawat atau bidan.

c. Tenaga kesehatan masyarakat yaitu sanitarian, epidemiolog kesehatan, entomolog kesehatan, penyuluh kesehatan, asisten apoteker atau analis laboratorium.

d. Tenaga gizi yaitu nutrisionis atau dietietik.

Tenaga Kesehatan Teladan adalah Petugas Kesehatan yang melakukan pengabdian, pekerjaan dan berprestasi dalam pembangunan pada lingkup kesehatan (RI, 2016).

Tujuan diselenggarakan pemilihan Petugas kesehatan teladan adalah untuk memberikan penghargaan bagi mereka yang bekerja dan mengabdi di Puskesmas. Penghargaan ini diharapkan dapat meningkatkan motivasi dan kinerja Petugas Kesehatan dalam memberikan pelayanan kepada masyarakat, dengan tidak membedakan lokasi tempat mereka ditugaskan. Untuk menghargai kinerja Petugas tersebut, Kemenkes memberikan penghargaan setiap tahun pada bulan Agustus bersamaan dengan Hari Kemerdekaan (RI, 2014). 


\subsection{Metode Multi-Attribute Utility Theory}

Multi-Attribute Utility Theory (MAUT) adalah adalah skema evaluasi yang sangat populer untuk mengevaluasi produk bagi pengguna. MAUT digunakan untuk mengidentifikasi dan menggali informasi tentang preferensi pengguna dalam konteks personal. Keseluruhan informasi tentang tingkah laku pengguna yang bersifat multidimensional dibagi menjadi beberapa bagian yang bersifat unidimensional untuk kemudian diberikan ukuran dan bobot. Pengukuran dan pembobotan dilakukan dengan mempertimbangkan setiap jenis konteks sebagai salah satu atribut item. Pengunaan pendekatan MAUT memungkinkan untuk penyaringan informasi sesuai preferensi pengguna dengan cara mengidentifikasi pengaruh dari beberapa atribut (Wang \& Meng, 2012).

Dalam metode MAUT digunakan untuk merubah dari beberapa kepentingan ke dalam nilai numerik dengan skala 0-1, 0 mewakili pilihan terburuk dan 1 terbaik. Hal ini memungkinkan perbandingan langsung beragam ukuran, yaitu dengan alat yang tepat. Hasil akhirnya adalah urutan peringkat dari evaluasi alternatif yang menggambarkan pilihan dari para pembuat keputusan. Evaluasi alternatif didapatkan dengan melakukan normalisasi bobot alternatif dengan Persamaan 1,

$U_{(x)}=\frac{x_{i}-x_{i}^{-}}{x_{i}^{+}-x_{i}^{-}}$

di mana $U(x)$ adalah normalisasi bobot alternatif, $x_{i}$ adalah bobot alternatif, $x_{i}^{-}$adalah bobot terburuk (minimum) dari kriteria ke- $x, x_{i}^{+}$adalah bobot terbaik (maximum) dari kriteria ke- $x$. Perhitungan utilitas normalisasi atribut didasarkan pada Persamaan 2,

$V_{(x)}=\sum_{i=1}^{n} w_{j} \times x_{i j}$

di mana $V_{(x)}$ nilai keseluruhan dari alternatif pilihan suatu subkriteria, $W_{j}$ bobot kriteria, $X_{i j}$ nilai alternatif pilihan suatu subkriteria, $i$ alternatif pilihan, $j$ subkriteria, $n$ jumlah sampel penelitian.

\section{Metode Penelitian}

\subsection{Perencanaan sistem}

Pada tahap perencanaan dilakukan pengumpulan data. Metode pengumpulan data yang digunakan adalah wawancara. Wawancara dilakukan untuk mendapatkan data mengenai tenaga kesehatan yang benar-benar akurat, sehingga hasil output dapat digunakan dan memberikan hasil rekomendasi yang terpercaya. Kedatangan ke Dinas Kesehatan Kabupaten Kutai Kartanegara dilakukan sebanyak 2 kali. Pertama dilakukan pada hari Senin tanggal 12 Februari 2018 pada pukul 9.00 - 10.30 WITA, kedua dilakukan pada hari Kamis tanggal 15 Februari 2018 pada pukul 14.00 - 15.30 WITA untuk mewawancarai kepala sub bagian kepegawaian di Dinas Kesehatan Kabupaten Kutai Kartanegara yang bernama Bapak Zam Zam, wawancara untuk melakukan penentuan kriteria dan bobot kriteria. Data penelitian didapatkan data kriteria dan bobot. Nilai subkriteria di lihat pada Tabel 1 dan kriteria pemilihan tenaga kesehatan teladan dapat dilihat pada Tabel 2.

Keterangan Tabel 2:

1) Sebagai penggerak pembangunan berwawasan kesehatan mempunyai 3 subkriteria, untuk mendapatkan nilai 61-100 disubkriteria dapat melihat penjelasannya dibawah ini:

a. Penggerak lintas sektor

Untuk mendapatkan nilai penggerak lintas sektor, panitia memverifikasi dokumentasi pertemuan lintas sektor, ada kegiatan terkait dalam usaha menjaga kesehatan masyarakat, dan dokumen peran serta masyarakat dalam penggalangan dana.

\begin{tabular}{clc}
\multicolumn{3}{c}{ Tabel 1. Nilai subkriteria } \\
\hline No & Keterangan & Nilai \\
\hline 1 & Amat Baik & $91-100$ \\
2 & Baik & $76-90$ \\
3 & Cukup & $61-75$ \\
\hline
\end{tabular}

b. Pemantauan

Untuk mendapatkan nilai Pemantauan, panitia memverifikasi peta permasalahan yang terkini.

c. Pelaporan 
Untuk mendapatkan nilai Pelaporan, panitia memverifikasi dokumen tertulis hasil pengamatan/pemantauan.

Tabel 2. Kriteria pemilihan tenaga kesehatan teladan

\begin{tabular}{|c|c|c|c|}
\hline No & Nama Kriteria & Subkriteria & Bobot \\
\hline 1 & $\begin{array}{l}\text { K1 sebagai penggerak pembangunan } \\
\text { berwawasan kesehatan }\end{array}$ & $\begin{array}{ll}\text { a. Penggerak lintas sektor } \\
\text { b. Pemantauan } \\
\text { c. Pelaporan }\end{array}$ & 15 \\
\hline 2 & K2 sebagai tenaga pemberdayaan masyarakat & a. Pemberdayaan perorangan & 20 \\
\hline 3 & $\begin{array}{l}\text { K3 sebagai pemberi pelayanan kesehatan } \\
\text { strata pertama }\end{array}$ & $\begin{array}{l}\text { b. Pemberdayaan kelompok/masyarakat } \\
\text { a. Perencanaan } \\
\text { b. Pengorganisasian } \\
\text { c. Pelaksanaan kegiatan } \\
\text { d. Pemantauan dan penilaian kegiatan }\end{array}$ & 20 \\
\hline 4 & K4 sebagai pegawai puskesmas & $\begin{array}{ll}\text { a. } & \text { Tanggung jawab } \\
\text { b. Kejujuran } \\
\text { c. Kerjasama } \\
\text { d. Prakarsa } \\
\text { e. Kepepimpinan }\end{array}$ & 15 \\
\hline 5 & K5 sebagai tenaga kesehatan profesional & $\begin{array}{l}\text { a. Keikutsertaan dalam bidang keilmuan } \\
\text { b. Hubungan dengan pasien/keluarga } \\
\text { pasien } \\
\text { c. Hubungan dengan rekan kerja }\end{array}$ & 20 \\
\hline 6 & K6 sebagai anggota masyarakat & $\begin{array}{l}\text { a. Kepribadian } \\
\text { b. Peran serta dalam masyarakat }\end{array}$ & 10 \\
\hline
\end{tabular}

2) Sebagai tenaga pemberdayaan masyarakat mempunyai 2 subkriteria, untuk mendapatkan nilai 61-100 di subkriteria dapat melihat penjelasannya di bawah ini:

a. Pemberdayaan

Untuk mendapatkan nilai pemberdayaan, panitia memverifikasi jumlah tatanan rumah tangga yang Berperilaku Hidup Bersih dan Sehat (PHBS) dan jumlah kader atau tokoh masyarakat yang peduli kesehatan.

b. Pemberdayaan kelompok/masyarakat

Untuk mendapatkan nilai pemberdayaan kelompok/masyarakat, panitia memverifikasi adanya dasa wisma, kelompok pengajian, kelompok budaya, kelompok adat, organisasi swasta, wanita, pemuda dan profesi yang berwawasan kesehatan sesuai dengan profesinya dan adanya upaya Kesehatan Bersumber

3) Sebagai pelayanan kesehatan strata pertama mempunyai 4 subkriteria, untuk mendapatkan nilai 61-100 di subkriteria dapat melihat penjelasannya di bawah ini:

a. Perencanaan

Untuk mendapatkan nilai perencanaan, panitia memverifikasi dokumen rencana usulan kegiatan dan dokumen Plan of Action (POA).

b. Pengorganisasian

Untuk mendapatkan nilai pengorganisasian, panitia memverifikasi dokumen uraian tugas dan dokumen rapat koordinasi.

c. Pelaksanaan kegiatan

Untuk mendapatkan nilainya, panitia memverifikasi dokumen hasil kegiatan.

d. Pemantauan dan penilaian kegiatan

Untuk mendapatkan nilai pemantauan dan penilaian kegiatan, panitia memverifikasi dokumen pemantauan, dokumen tindak lanjut dan dokumen penilaian kegiatan.

4) Sebagai pegawai puskesmas mempunyai 4 subkriteria, untuk mendapatkan nilai 61-100 di subkriteria dapat melihat penjelasannya di bawah ini:

a. Tanggung jawab

Untuk mendapatkan nilai tanggung jawab, panitia memverifikasi tingkat kehadiran.

b. Kejujuran 
Untuk mendapatkan nilai kejujuran, panitia memverifikasi tidak ada laporan negatif dari masyarakat/pegawai.

c. Kerjasama

Untuk mendapatkan nilai kerjasama, panitia memverifikasi dokumen pembagian tugas dan dokumen laporan hasil kegiatan.

d. Prakarsa

Untuk mendapatkan nilai prakarsa, panitia memverifikasi dokumen reward dan punishment.

e. Kepepimpinan

Untuk mendapatkan nilai kepemimpinan, panitia memverifikasi mempunyai inisiatif untuk menyelesaikan masalah dan memberi motivasi.

5) Sebagai tenaga kesehatan profesional mempunyai 3 subkriteria, untuk mendapatkan nilai 61-100 di subkriteria dapat melihat penjelasannya di bawah ini:

a. Keikutsertaan

Untuk mendapatkan nilai keikutsertaan dalam bidang keilmuan, panitia memverifikasi dokumen inovasi dalam pelaksanaan program kesehatan, dokumen artikel yang dipublikasi, tanda pengurus/anggota dari almamaternya, sertifikat tanda kelulusan pendidikan tambahan yang diikuti dan sertifikat tanda kepesertaan seminar pelatihan.

b. Hubungan dengan pasien/keluarga

Untuk mendapatkan nilai hubungan dengan pasien/keluarga pasien, panitia memverifikasi angka kepuasan pasien mendekati $100 \%$ dan tidak ada keluhan dari masyarakat.

c. Hubungan dengan rekan

Untuk mendapatkan nilai hubungan dengan rekan kerja, panitia memverifikasi tanda pengenal pengurus/anggota organisasi profesi dan tidak ada keluhan dari rekan sekerja.

6) Sebagai anggota Masyarakat mempunyai 2 subkriteria, untuk mendapatkan nilai 61-100 di subkriteria dapat melihat penjelasannya di bawah ini:

a. Kepribadian

Untuk mendapatkan nilai kepribadian, panitia memverifikasi berperilaku hidup sehat dan bersih.

b. Peran serta dalam masyarakat

Untuk mendapatkan nilai peran serta dalam masyarakat, panitia memverifikasi kartu tanda pengurus/ anggota organisasi kemasyarakatan.

\subsection{Contoh perhitungan metode MAUT}

Contoh nilai:

$A_{1}=\{5,10,15\}$

$A_{2}=\{3,11,30\}$

Bobot $=\{2,4,6\}$

Normalisasi matriks menggunakan Persamaan 1,

$$
\begin{array}{lll}
U_{(1,1)}=\frac{(5-3)}{(5-3)}=1 & U_{(1,2)}=\frac{(10-10)}{(11-10)}=0 & U_{(1,3)}=\frac{(15-15)}{(30-15)}=0 \\
U_{(2,1)}=\frac{(3-3)}{(5-3)}=0 & U_{(2,2)}=\frac{(11-10)}{(11-10)}=1 & U_{(2,3)}=\frac{(30-15)}{(30-15)}=1
\end{array}
$$

perangkirngan alternaif dengan Persamaan 2,

$$
A_{1}=(2 \times 1)+(4 \times 0)+(6 \times 0)=2+0+0=2
$$

$A_{2}=(2 \times 0)+(4 \times 1)+(6 \times 1)=0+4+6=10$

dari hasil perhitungan normalisasi matriks dan perangkingan alternatif dapat disimpulkan bahwa alternatif yang terpilih adalah alternatif A2.

\subsection{Perancangan sistem}

Rancangan alur sistem merupakan rancangan yang menjelaskan alur dalam pengoperasian SPK pemilihan tenaga kesehatan teladan ketika digunakan oleh pengguna. Alur sistem dirancang sesuai dengan tahapan yang telah dilakukan sebelumnya. Flowchart sistem dapat dilihat pada Gambar 1 . Perancangan use case diagram pada SPK pemilihan tenaga kesehatan teladan dirancang sesuai kebutuhan sistem yang dibangun. Use case diagram merupakan gambaran fungsional dari sistem, sehingga aktor yang dalam hal ini adalah admin dapat mengerti serta memahami fungsinya pada sistem. 
Selain use case diagram juga dirancang activity diagram, activity diagram ini menjelaskan mengenai alur-alur kegiatan yang dapat dilakukan oleh admin terhadap sistem yang telah dibangun. Terdapat enam form, yaitu form login, form input data, form perhitungan MAUT, form data kriteria, form penilaian tambahan dan form input nilai. Pada form input data terdapat empat proses, yang pertama tambah data, kedua edit data, ketiga hapus data dan kelima simpan data. Selanjutnya data dihitung menggunakan metode MAUT. Dari data yang telah dihitung, admin dapat melihat hasil yang terdapat pada form penilaian. Agar lebih jelas bisa dilihat pada Gambar 2.

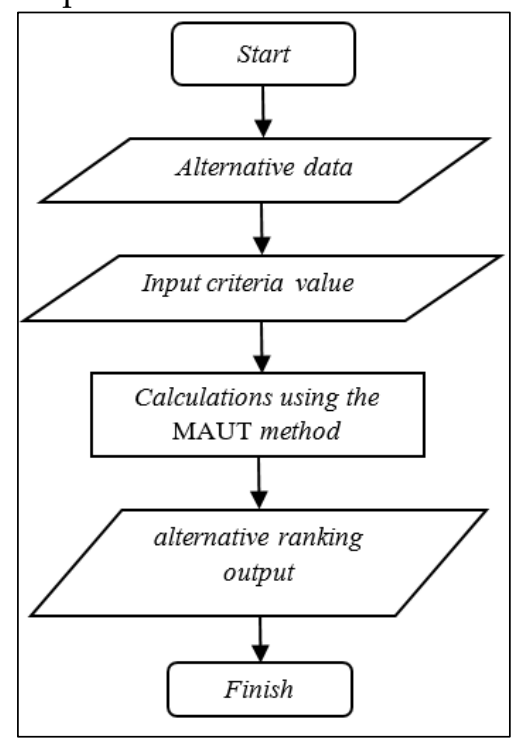

Gambar 1. Flowchart sistem

\section{Hasil dan Pembahasan}

\subsection{Implementasi sistem}

Sistem pendukung keputusan pemilihan tenaga kesehatan teladan menggunakan metode MAUT merupakan sistem aplikasi berbasis dekstop. Sistem ini memudahkan pengguna dalam menentukan perangkingan sehingga menghasilkan rekomendasi tenaga kesehatan teladan sesuai dengan kriteria. Halaman login admin merupakan halaman awal admin untuk masuk kedalam menu-menu pada sistem pemilihan tenaga kesehatan teladan ini, tetapi sebelum itu admin harus menginputkan user name dan password sebagai pengamanan sistem dalam pengelolaan data-data sistem ini. Halaman login admin bisa dilihat pada Gambar 3.

Setelah login dilakukan, maka admin akan masuk ke halaman beranda seperti pada Gambar 4 . Beberapa tahapan yang dilakukan admin untuk dapat melakukan perhitungan metode MAUT. Tahapan pertama yaitu input data alternatif. Pada halaman ini, admin dapat melakukan pengelolaan data dari calon tenaga kesehatan teladan seperti memasukkan, mengubah, menghapus dan menyimpan data. Adapun halaman input data alternatif dapat dilihat pada Gambar 5.

Tahapan kedua yaitu memasukkan nilai alternatif sesuai data kriteria dan subkriteria. Halaman input nilai alternatif dapat dilihat pada Gambar 6. Halaman perhitungan merupakan halaman yang digunakan oleh admin, fitur perhitungan MAUT dapat dilihat pada Gambar 7.

Halaman laporan adalah halaman yang digunakan oleh admin untuk melakukan pencetakan laporan. Pada halaman ini terdapat beberapa hal yang harus dilakukan sebelum mencetak laporan, yaitu memilih semua jabatan. Adapun halaman dari cetak laporan dapat dilihat pada Gambar 8.

\subsection{Pengujian metode MAUT}

Pengujian sistem dilakukan untuk mengetahui apakah sistem yang dibuat sesuai dengan tujuan. Uji coba dilakukan dengan menggunakan perhitungan manual. Dilakukan uji coba terhadap 3 data calon tenaga kesehatan teladan yang sudah ada dengan nilai bobot untuk menetukan rekomendasi calon tenaga kesehatan teladan yang sesuai pada kriteria yang digunakan.

Ada 3 calon tenaga kesehatan teladan dilakukan pengujian secara manual, yaitu:

1) $\mathrm{A} 1=$ Eka Lestari, Amd.Keb

2) $\mathrm{A} 2$ = Rahmatina, Amd.Keb

3) A3 $=$ Dr. H. Yazid Muchammad Nur

Sistem pendukung keputusan pemilihan tenaga kesehatan teladan ...

(c) 2019 Register: Jurnal Ilmiah Teknologi Sistem Informasi. Semua hak cipta dilindungi undang-undang. 


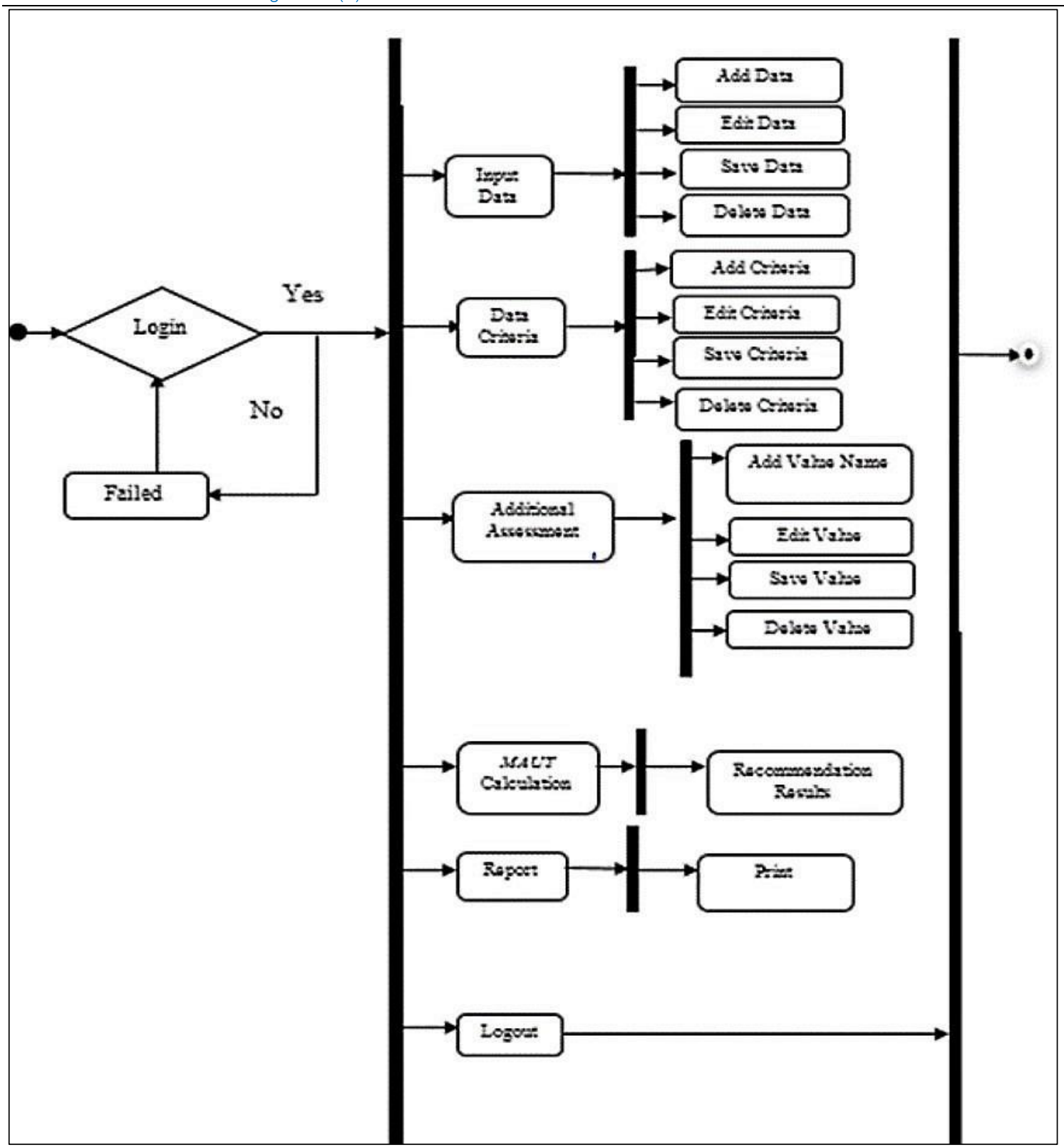

Gambar 2. Activity diagram sistem

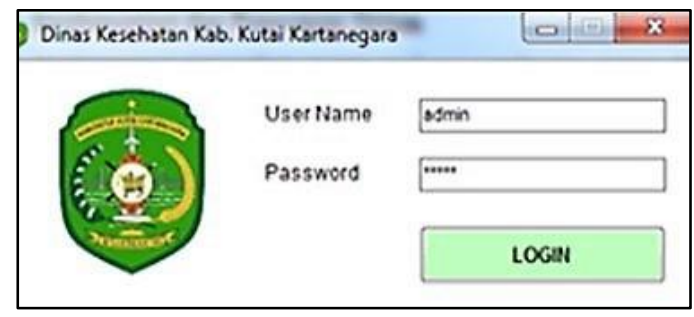

Gambar 3. Halaman Login

Langkah pertama yang dilakukan pada metode MAUT adalah normalisasi matrik dari data pada Gambar 9 dengan Persamaan 1,

Alternatif 1
$\mathrm{A} 1 \mathrm{~K} 1_{1}=\frac{95-94}{98-95}=0,25$
$\mathrm{A} 1 \mathrm{~K} 1_{2}=\frac{95-95}{99-95}=0$
$\mathrm{A} 1 \mathrm{~K} 2_{1}=\frac{90-90}{96-90}=0$
$\mathrm{A} 1 \mathrm{~K}_{2}=\frac{97-96}{97-96}=1$
$\mathrm{A} 1 \mathrm{~K} 2_{2}=\frac{92-91}{95-91}=0,25$
$\mathrm{A} 1 \mathrm{~K}_{3}=\frac{98-97}{100-97}=0,33$
$\mathrm{A} 1 \mathrm{~K} 4_{1}=\frac{99-98}{100-98}=0,5$
$\mathrm{A} 1 \mathrm{~K} 4_{2}=\frac{97-96}{97-96}=1$
$\mathrm{A} 1 \mathrm{~K} 1_{3}=\frac{94-93}{95-93}=0,5$
$\mathrm{A} 1 \mathrm{~K}_{1}=\frac{98-97}{99-97}=0,5$
$\mathrm{A} 1 \mathrm{~K}_{4}=\frac{94-93}{95-93}=0,5$
$\mathrm{A} 1 \mathrm{~K} 4_{3}=\frac{98-97}{100-97}=0,33$

Sistem pendukung keputusan pemilihan tenaga kesehatan teladan ...

(c) 2019 Register: Jurnal IImiah Teknologi Sistem Informasi. Semua hak cipta dilindungi undang-undang. 


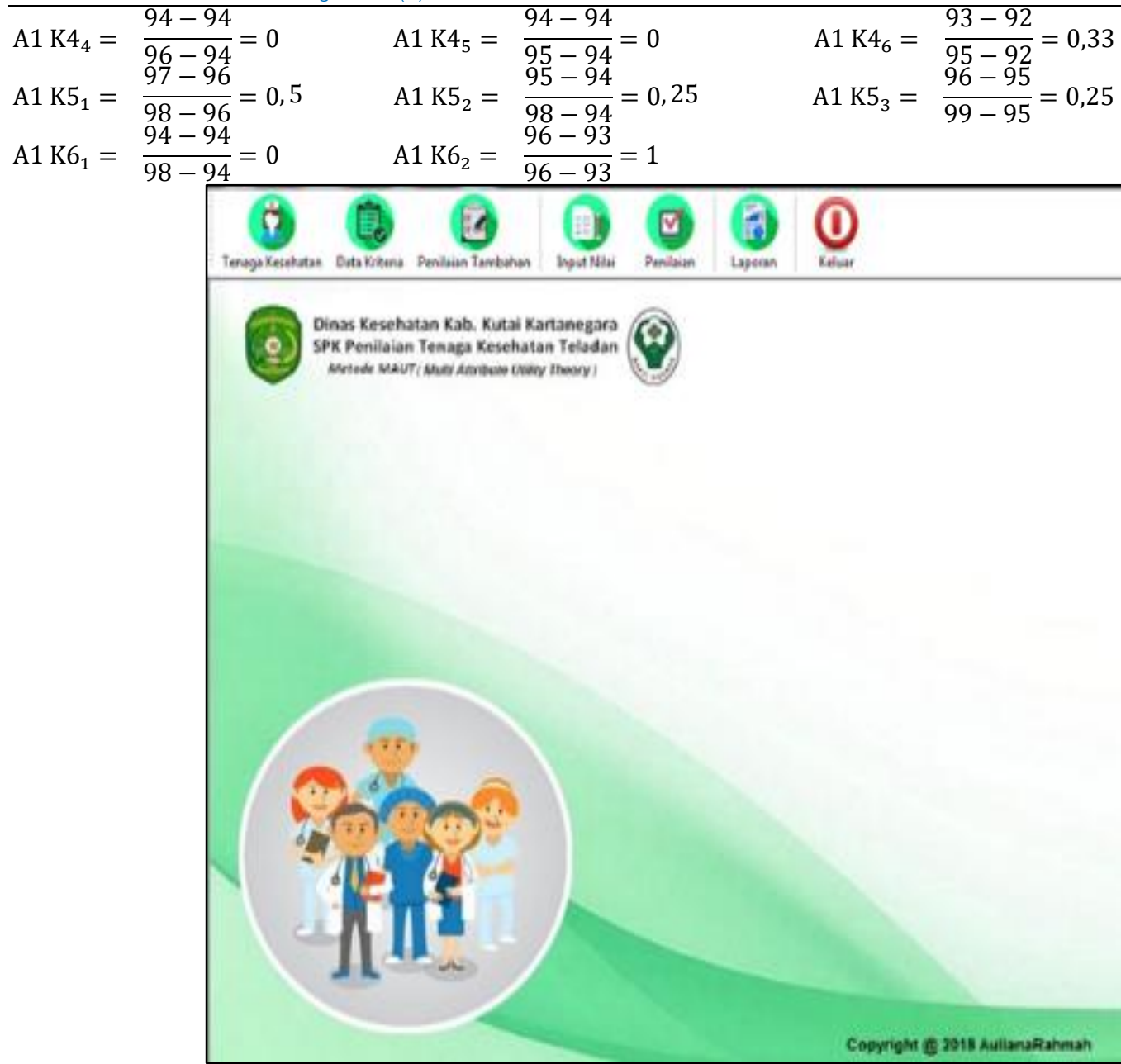

Gambar 4. Halaman Beranda

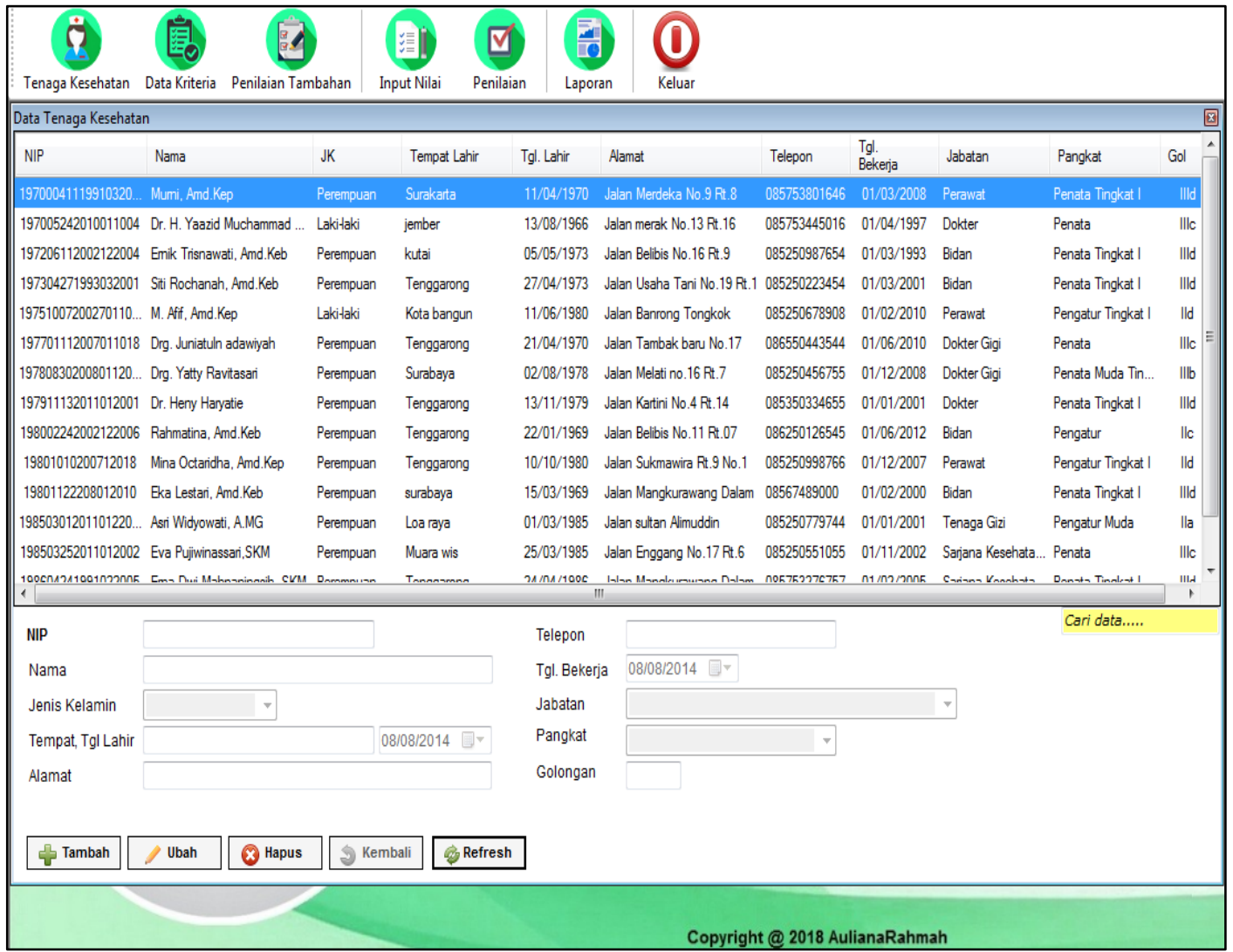

Gambar 5. Halaman input data alternatif 


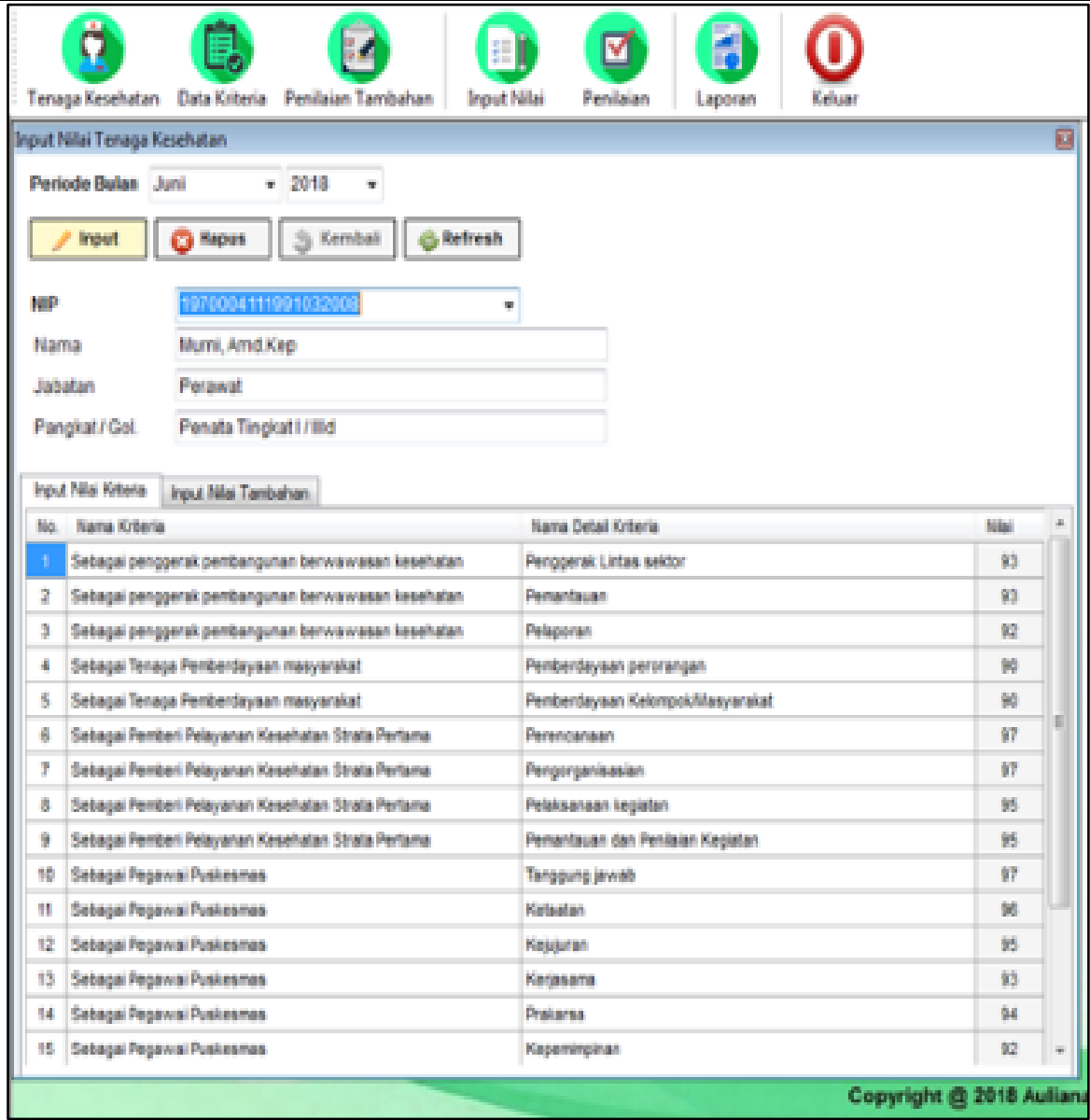

Gambar 6. Halaman input nilai alternatif

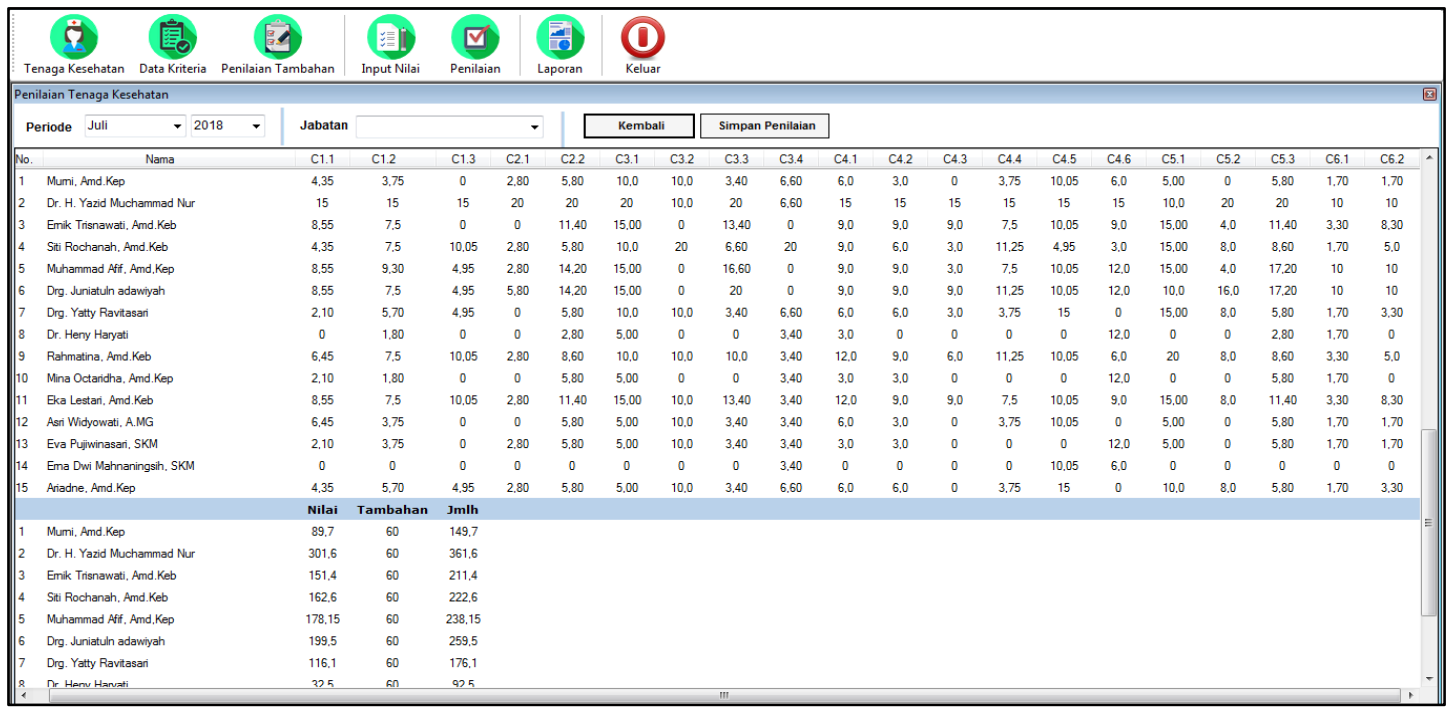

Gambar 7. Halaman perhitungan metode MAUT

Alternatif 2
$\mathrm{A} 2 \mathrm{~K} 1_{1}=\frac{94-94}{98-95}=0$
$\mathrm{A} 2 \mathrm{~K}_{2}=\frac{95-95}{99-95}=0$
$\mathrm{A} 2 \mathrm{~K}_{1}=\frac{90-90}{96-90}=0$
$\mathrm{A} 2 \mathrm{~K}_{2}=\frac{91-91}{95-91}=0$
$\mathrm{A} 2 \mathrm{~K}_{2}=\frac{97-96}{97-96}=1$
$\mathrm{A} 2 \mathrm{~K}_{1}=\frac{99-98}{100-98}=0,5$
$\mathrm{A} 2 \mathrm{~K}_{3}=\frac{97-97}{100-97}=0$
$\mathrm{A} 2 \mathrm{~K}_{2}=\frac{98-98}{100-98}=0$
$\mathrm{A} 2 \mathrm{~K}_{4}=\frac{95-94}{96-94}=0,5$
$\mathrm{A} 2 \mathrm{~K}_{5}=\frac{94-94}{95-94}=0$
$\begin{aligned} \mathrm{A} 2 \mathrm{~K}_{3} & =\frac{94-93}{95-93}=0,5 \\ \mathrm{~A} 2 \mathrm{~K}_{1} & =\frac{97-97}{99-97}=0 \\ \mathrm{~A} 2 \mathrm{~K}_{4} & =\frac{94-93}{95-93}=0,5 \\ \mathrm{~A} 2 \mathrm{~K}_{3} & =\frac{97-97}{100-97}=0 \\ \mathrm{~A} 2 \mathrm{~K}_{6} & =\frac{92-92}{95-92}=0\end{aligned}$

Sistem pendukung keputusan pemilihan tenaga kesehatan teladan ... 


$\begin{array}{lll}\mathrm{A} 2 \mathrm{~K} 5_{1}=\frac{98-96}{98-96}=1 & \mathrm{~A} 2 \mathrm{~K} 5_{2}=\frac{95-94}{98-94}=0,25 & \mathrm{~A} 2 \mathrm{~K} 5_{3}=\frac{95-95}{99-95}=0 \\ \mathrm{~A} 2 \mathrm{~K} 6_{1}=\frac{94-94}{98-94}=0 & \mathrm{~A} 2 \mathrm{~K} 6_{2}=\frac{93-93}{96-93}=0 & \end{array}$

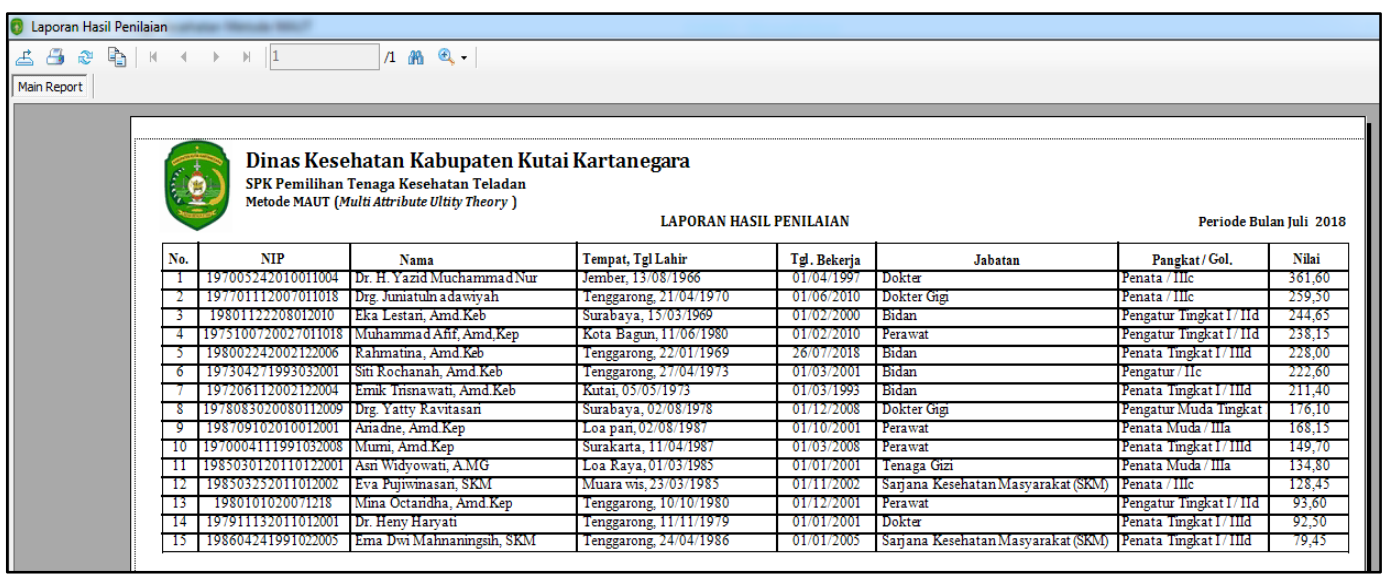

Gambar 8. Halaman Laporan

\begin{tabular}{|c|c|c|c|c|c|c|c|c|c|c|c|c|c|c|c|c|c|c|c|c|c|}
\hline \multirow{2}{*}{ No } & \multirow{2}{*}{ Alternatif } & \multicolumn{3}{|c|}{ K1 } & \multicolumn{2}{|c|}{ K2 } & \multicolumn{4}{|c|}{ K3 } & \multicolumn{6}{|c|}{ K4 } & \multicolumn{3}{|c|}{ K5 } & \multicolumn{2}{|c|}{ K6 } \\
\hline & & 1 & 2 & 3 & 1 & 2 & 1 & 2 & 3 & 4 & 1 & 2 & 3 & 4 & 5 & 6 & 1 & 2 & 3 & 1 & 2 \\
\hline 1 & Eka Lestari, Amd.Keb & 95 & 95 & 94 & 90 & 92 & 98 & 97 & 98 & 94 & 99 & 98 & 98 & 94 & 94 & 93 & 97 & 95 & 96 & 94 & 95 \\
\hline 2 & Rahmatina, Amd.Keb & 94 & 95 & 94 & 90 & 91 & 97 & 97 & 97 & 94 & 99 & 98 & 97 & 95 & 94 & 92 & 98 & 95 & 95 & 94 & 93 \\
\hline 3 & Dr. H. Yazid Muchammad Nur & 98 & 99 & 95 & 96 & 95 & 99 & 97 & 100 & 95 & 100 & 100 & 100 & 96 & 95 & 95 & 96 & 98 & 99 & 98 & 96 \\
\hline
\end{tabular}

Gambar 9. Rating kecocokan

Alternatif 3

$\begin{array}{rlrl}\mathrm{A} 3 \mathrm{~K} 1_{1} & =\frac{98-94}{98-95}=1,33 & \mathrm{~A} 3 \mathrm{~K} 1_{2}=\frac{99-95}{99-95}=1 & \mathrm{~A} 3 \mathrm{~K} 1_{3}=\frac{95-93}{95-93}=1 \\ \mathrm{~A} 3 \mathrm{~K} 2_{1}=\frac{96-90}{96-90}=1 & \mathrm{~A} 3 \mathrm{~K} 2_{2}=\frac{95-91}{95-91}=1 & \mathrm{~A} 3 \mathrm{~K} 3_{1}=\frac{99-97}{99-97}=1 \\ \mathrm{~A} 3 \mathrm{~K} 3_{2}=\frac{97-96}{97-96}=1 & \mathrm{~A} 3 \mathrm{~K} 3_{3}=\frac{100-97}{100-97}=1 & \mathrm{~A} 3 \mathrm{~K} 3_{4}=\frac{95-93}{95-93}=1 \\ \mathrm{~A} 3 \mathrm{~K} 4_{1}=\frac{100-98}{100-98}=1 & \mathrm{~A} 3 \mathrm{~K} 4_{2}=\frac{100-98}{100-98}=1 & \mathrm{~A} 3 \mathrm{~K}_{3}=\frac{100-97}{100-97}=1 \\ \mathrm{~A} 3 \mathrm{~K} 4_{4}=\frac{96-94}{96-94}=1 & \mathrm{~A} 3 \mathrm{~K} 4_{5}=\frac{95-94}{95-94}=1 & \mathrm{~A} 3 \mathrm{~K} 4_{6}=\frac{95-92}{95-92}=1 \\ \mathrm{~A} 3 \mathrm{~K} 5_{1}=\frac{96-96}{98-96}=0 & \mathrm{~A} 3 \mathrm{~K} 5_{2}=\frac{98-94}{98-94}=1 & \mathrm{~A} 3 \mathrm{~K} 5_{3}=\frac{99-95}{99-95}=1 \\ \mathrm{~A} 3 \mathrm{~K} 6_{1}=\frac{98-94}{98-94}=1 & \mathrm{~A} 3 \mathrm{~K}_{2}=\frac{96-93}{96-93}=1 & \end{array}$

Langkah kedua perhitungan perkalian matrik normalisasi dengan menggunakan Persamaan 2,

$\mathrm{A} 1=(0,25 \times 15)+(0 \times 15)+(0,5 \times 15)+(0 \times 20)+(0,25 \times 20)+(0,5 \times 20)+(1 \times 20)+(0,33 \times 20)+(0,5 \times 20)+(0,5 \times$

$15)+(1 \times 15)+(0,33 \times 15)+(0 \times 15)+(0 \times 15)+(0,33 \times 15)+(0,5 \times 20)+(0,25 \times 20)+(0,25 \times 20)+(0 \times 10)+$ $(1 \times 10)$

$=(3,75+0+7,5+0+5+10+20+6.6+10+7,5+15+4,95+0+0+4,95+10+5+5+0+10)$

$=131,95$

$\mathrm{A} 2=(0 \times 15)+(0 \times 15)+(0,5 \times 15)+(0 \times 20)+(0 \times 20)+(0 \times 20)+(1 \times 20)+(0 \times 20)+(0,5 \times 20)+(0,5 \times 15)+(0 \times$

$15)+(0 \times 15)+(0,5 \times 15)+(0 \times 15)+(0 \times 15)+(1 \times 20)+(0,25 \times 20)+(0 \times 20)+(0 \times 10)+(0 \times 10)$

$=(0+0+7,5+0+0+0+20+0+10+7,5+0+7,5+0+0+0+20+5+0+0+0)$

$=77,5$

A3 $=(1,33 \times 15)+(1 \times 15)+(1 \times 15)+(1 \times 20)+(1 \times 20)+(1 \times 20)+(1 \times 20)+(1 \times 20)+(1 \times 20)+(1 \times 15)+(1 \times$ $15)+(1 \times 15)+(1 \times 15)+(1 \times 15)+(1 \times 15)+(0 \times 20)+(1 \times 20)+(1 \times 20)+(1 \times 10)+(1 \times 10)$ $=(19,95+15+15+20+20+20+20+20+20+15+15+15+15+15+15+0+20+20+10+10)$ $=319,95$

Langkah terakhir adalah proses perangkingan. Hasil perangkingan diperoleh dengan nilai akhir pada $A_{1}=106,95 ; A_{2}=77,5$ dan $A_{3}=319,95$, maka rekomendasi yang diperoleh dengan nilai tertinggi dan terbesar ada pada $\mathrm{A}_{3}$, sehingga alternatif $\mathrm{A}_{3}$ adalah alternatif yang terpilih sebagai alternatif dengan tenaga kesehatan teladan yaitu tenaga kesehatan atas nama Dr. H. Yazid Muchammad Nur. Hasil 
perhitungan tersebut didapatkan beberapa rekomendasi untuk tenaga kesehatan teladan bisa dilihat pada Tabel 4.

Tabel 4. Hasil tenaga kesehatan teladan dengan perhitungan manual

\begin{tabular}{clcc}
\hline \multirow{2}{*}{ Alternatif } & \multicolumn{1}{c}{ Nama } & Nilai & Rekomendasi \\
\hline A3 & Dr. H. Yazid Muchammad & 319,95 & 1 \\
A1 & Eka Lestari, Amd. Keb & 131,9 & 2 \\
A2 & Rahmatina, Amd.Keb & 77,5 & 3 \\
\hline
\end{tabular}

\subsection{Perhitungan nilai akurasi}

Hasil pengujian SPK pemilihan tenaga kesehatan teladan menggunakan metode MAUT didapatkan rumus untuk mengukur tingkat akurasi sistem dengan data asli dari Dinas Kesehatan Kabupaten Kutai Kartanegara. Untuk menghitung tingkat akurasi sistem:

a. Jumlah sampel tenaga kesehatan : : 15

b. Jumlah sesuai data asli $\quad: 13$

c. Jumlah tidak sesuai data asli $\quad: 2$

di mana $N$ adalah total sesuai, $N_{i}$ adalah total tidak sesuai.

$$
\text { Akurasi }=\frac{N}{N+N i} \times 100 \%
$$

$$
\text { Akurasi }=\frac{13}{13+2} \times 100 \%=86,67 \%
$$

Dilihat dari rumus perhitungan di atas, nilai akurasi yang dihasilkan dalam penelitian ini sebesar 86,67\%. Data yang digunakan sejumlah 15 data yang ada pada data asli atau manual, yang secara seluruh sudah sesuai. Data dapat diinputkan ke dalam sistem yang dibuat. Walaupun begitu, masih terdapat beberapa ketidaksesuaian dari hasil perangkingan akhir, dikarenakan selisih perhitungan bobot akhir dari sistem dengan bobot akhir dari data manual. Untuk perbedaan yang terdapat pada hasil perhitungan data manual dan data sistem, diakibatkan karena adanya selisih dari hasil perkalian matrik ternormalisasi dengan kriteria preferensi. Karena selisih peringkat dari kedua data di atas tidak berbeda jauh, maka selisih tersebut tidak mempengaruhi hasil akhir perangkingan dari data manual dan sistem.

\section{Kesimpulan}

Berdasarkan hasil penelitian yang telah dilakukan, maka dapat diambil beberapa kesimpulan antara lain, telah dihasilkan SPK Pemilihan Tenaga Kesehatan Teladan menggunakan metode Multi-Attribute Utility Theory (MAUT) yang mampu memberikan rekomendasi pemilihan tenaga kesehatan teladan. Penerapan metode MAUT memberikan hasil akurasi sebesar $86,67 \%$, dari hasil tersebut menunjukkan bahwa metode MAUT bisa menjadi metode alternatif untuk sistem pemilihan tenaga kesehatan teladan. SPK ini bisa dikembangkan dengan menggnakan metode lainnya seperti SMART, TOPSIS dan SAW untuk pembanding dan keakuratan dari hasil penelitian.

\section{Referensi}

Cholil, S. R., Pinem, A. P., \& Vydia, V. (2018). Implementasi metode Simple Multi Attribute Rating Technique untuk penentuan prioritas rehabilitasi dan rekonstruksi pascabencana alam. Register: Jurnal Ilmiah Teknologi Sistem Informasi, 4(1), 1-6.

Heliana, N. (2017). Seleksi Penerima Bantuan Beras Sejahtera Menggunakan Metode Multi Objective Optimization on the Basis of Ratio Analysis (MOORA) dan metode Weighted Sum Model (WSM). Samarinda: Universitas Mulawarman.

Indonesia, R. (1996). Peraturan Pemerintah Nomor 32 Tahun 1996 tentang Tenaga Kesehatan. Jakarta. Indonesia, R. (2014). Undang-Undang Republik Indonesia Nomor 36 Tahun 2014 Tentang Tenaga Kesehatan. Jakarta, Indonesia. Retrieved from https://www.kemenkopmk.go.id/sites/default/files/produkhukum/UU\%20Nomor\%2036\%20Tahu n\%202014.pdf 
Ramadiani, R., \& Kurniawan, R. (2018). Application of Technique for Order Preference Method by Similarity to Ideal Solution (TOPSIS) Priority of KORPRI Housing Recipient. International Journal of Engineering, Information Science and Applied Sciences (IJEIS-AS), 1(1), 1-8.

Ramadiani, R., Marissa, D., Jundillah, M. L., Azainil, A., \& Hatta, H. R. (2018). Simple Additive Weighting to Diagnose Rabbit Disease. In E3S Web of Conferences. 31, p. 10002. Semarang: EDP Sciences.

RI, K. (2014). Pedoman Penilaian Tenaga Kesehatan Teladan di Puskesmas. Jakarta: Kemenkes RI. Retrieved from https://edoc.site/buku-nakes-teladan-2014-pdf-free.html

RI, K. (2016). Peraturan Menteri Kesehatan Republik Indonesia Nomor 23 Tahun 2016 Tentang Pedoman Penyelenggaraan Pemberian Penghargaan Bagi Tenaga Kesehatan Teladan Di Pusat Kesehatan Masyarakat. Jakarta. Retrieved from http://ditjenpp.kemenkumham.go.id/arsip/bn/2016/bn830-2016.pdf

Siswo, R. A. (2017). Sistem Pendukung Keputusan Untuk Penerimaan Karyawan Pt Pln Jember Menggunakan Metode Multi Attribute Utility Theory (MAUT). Jember: Universitas Muhammadiyah Jember.

Wang, L., \& Meng, X. (2012). A MAUT Approach to Elicitation of Contextual User Preferences. AISS: Advances in Information Sciences and Service Sciences, 4(5), 98-105. 